PREPARED FOR THE U.S. DEPARTMENT OF ENERGY, UNDER CONTRACT DE-AC02-76CH03073

PPPL-3671

PPPL-3671

UC-70

Oxidative Tritium Decontamination System

by

Charles A. Gentile, John J. Parker,

Gregory L. Guttadora, and Lloyd P. Ciebiera

February 2002

MV|

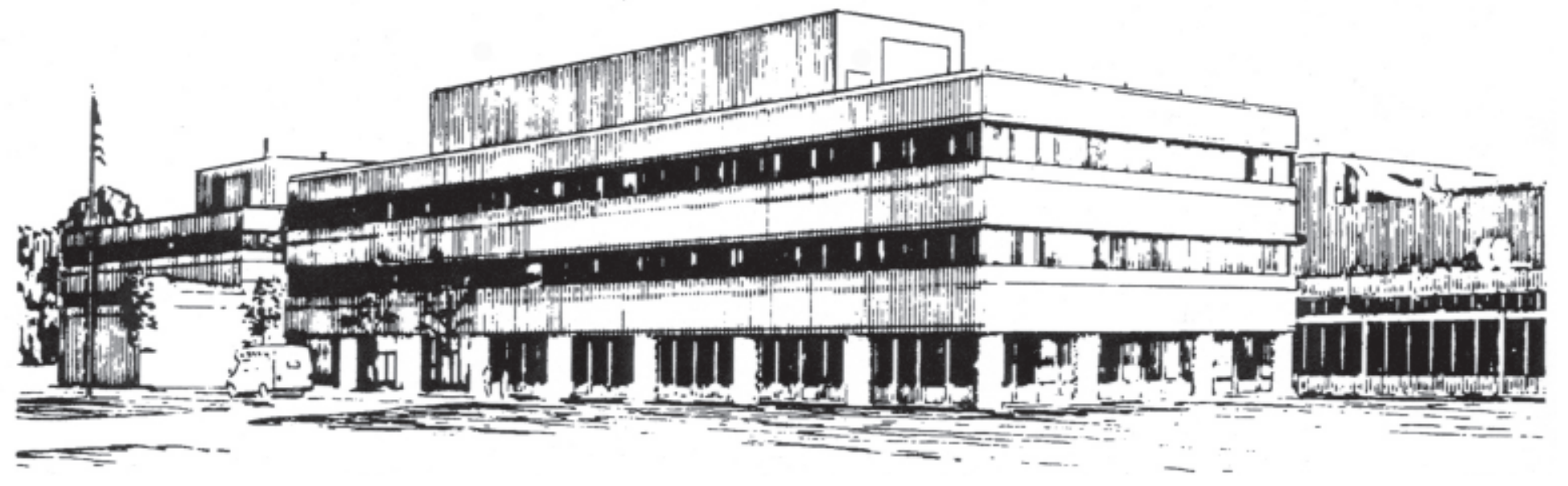

PRINCETON PLASMA PHYSICS LABORATORY PRINCETON UNIVERSITY, PRINCETON, NEW JERSEY 


\section{PPPL Reports Disclaimer}

This report was prepared as an account of work sponsored by an agency of the United States Government. Neither the United States Government nor any agency thereof, nor any of their employees, makes any warranty, express or implied, or assumes any legal liability or responsibility for the accuracy, completeness, or usefulness of any information, apparatus, product, or process disclosed, or represents that its use would not infringe privately owned rights. Reference herein to any specific commercial product, process, or service by trade name, trademark, manufacturer, or otherwise, does not necessarily constitute or imply its endorsement, recommendation, or favoring by the United States Government or any agency thereof. The views and opinions of authors expressed herein do not necessarily state or reflect those of the United States Government or any agency thereof.

\section{Availability}

This report is posted on the U.S. Department of Energy's Princeton Plasma Physics Laboratory Publications and Reports web site in Fiscal Year 2002. The home page for PPPL Reports and Publications is: http://www.pppl.gov/pub_report/

DOE and DOE Contractors can obtain copies of this report from:

U.S. Department of Energy

Office of Scientific and Technical Information

DOE Technical Information Services (DTIS)

P.O. Box 62

Oak Ridge, TN 37831

Telephone: (865) 576-8401

Fax: (865) 576-5728

Email: reports@adonis.osti.gov

This report is available to the general public from:

National Technical Information Service

U.S. Department of Commerce

5285 Port Royal Road

Springfield, VA 22161

Telephone: 1-800-553-6847 or

(703) 605-6000

Fax: (703) 321-8547

Internet: http://www.ntis.gov/ordering.htm 


\title{
Oxidative Tritium Decontamination System
}

\author{
Charles A. Gentile, John J. Parker, Gregory L. Guttadora, and Lloyd P. Ciebiera \\ Princeton Plasma Physics Laboratory, P.O. Box 451, Princeton, NJ 08543
}

\begin{abstract}
The Princeton Plasma Physics Laboratory, Tritium Systems Group has developed and fabricated an Oxidative Tritium Decontamination System (OTDS), which is designed to reduce tritium surface contamination on various components and items. The system is configured to introduce gaseous ozone into a reaction chamber containing tritiated items that require a reduction in tritium surface contamination. Tritium surface contamination (on components and items in the reaction chamber) is removed by chemically reacting elemental tritium to tritium oxide via oxidation, while purging the reaction chamber effluent to a gas holding tank or negative pressure HVAC system. Implementing specific concentrations of ozone along with catalytic parameters [1], the system is able to significantly reduce surface tritium contamination on an assortment of expendable and non-expendable items. This paper will present the results of various experimentation involving employment of this system [2].
\end{abstract}

\section{INTRODUCTION}

$\mathrm{P}$ RINCETON Plasma Physics Laboratory has developed a method by which to reduce tritium activity of contaminated materials/components to levels permissible for free release $\left(<16.6 \mathrm{~Bq} / 100 \mathrm{~cm}^{2}\right)$ or re-use within the site. This technology has the potential to significantly reduce costs associated with the disposal of expendable Personal Protective Equipment (PPE; i.e. Anti-C gloves, shoe covers, etc.) and Mixed Low Level Waste (MLLW). In addition, decommissioned tritium fusion reactor components can be decontaminated for re-use in future fusion devices and/or nonradiological environments [3].

\section{BACKGROUND}

Motivation to develop an ozone-induced decontamination process has arisen, in part, due to the success of tritium removal from Tokamak Fusion Test Reactor (TFTR) components (RF Feedthrough components - Fig. 1, Table I) via a similar process employing hydrogen peroxide $\left(\mathrm{H}_{2} \mathrm{O}_{2}\right.$, aqueous) as the oxidizing agent. It was discovered that post $\mathrm{H}_{2} \mathrm{O}_{2}$ process activity levels dropped significantly, and that there was no discernable surface regrowth noted after an approximate eight month hold time. This method, however, produces liquid effluent, which must then be disposed of as radiological waste [4]. A gas phase system allows for bulk collection and/or recycle of tritium, via molecular sieve, gas holding tank, tritium purification (isotope separation), etc. [3].

Funding for the development of this technology was provided by United States Department of Energy Contract Number DE-AC02-76CH03073.

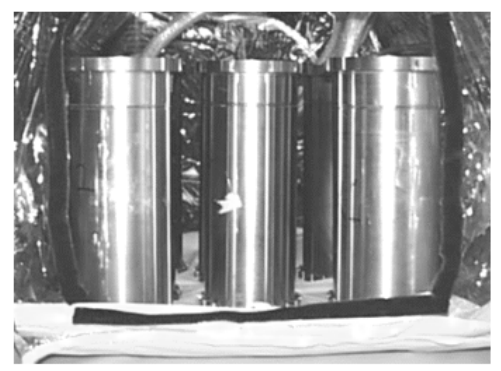

Stainless Steel RF

Feedthrough Components

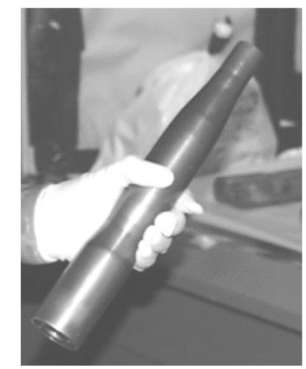

Copper Internal Conductor Component
Fig. 1 Photographs taken of RF Feedthrough Components that were removed from decommissioned TFTR.

TABLE I

$\mathrm{H}_{2} \mathrm{O}_{2}$ DECONTAMINATION OF TFTR RF FEEDTHROUGH COMPONENTS

\begin{tabular}{lrcc} 
& \multicolumn{3}{c}{ Date of Survey (MM/DD/YY) } \\
\hline RF Feedthrough & $8 / 19 / 00$ & $9 / 14 / 00$ & $5 / 02 / 01$ \\
Survey Location & $\mathrm{Bq} / 100 \mathrm{~cm}^{2}$ & $\mathrm{~Bq} / 100 \mathrm{~cm}^{2}$ & $\mathrm{~Bq} / 100 \mathrm{~cm}^{2}$ \\
\hline Outside Ctr. Cond. & 16973.90 & 0.85 & 0.12 \\
Inside Ctr. Cond. & 1355.85 & 1.08 & 0.98 \\
Outside Outer Cond. & 44.97 & 0.50 & 0.28 \\
Conductor Area & 15481.93 & 0.80 & 1.00 \\
Main Body Seal Area & 1393.50 & 0.65 & 0.22 \\
\hline
\end{tabular}

Data represents smear surveys taken from before $\mathrm{H}_{2} \mathrm{O}_{2}$ Process, after $\mathrm{H}_{2} \mathrm{O}_{2}$ Process, and after approximately 8 months in storage.

\section{SYSTEM CONFIGURATION}

Various intended applications have led to the design and fabrication of two OTDS system configurations. These configurations are identical in concept, yet each allows for a different set of variables/parameters to be applied. A rotary system is implemented for decontamination of light materials (PPE, MLLW). Variables/Parameters such as agitation mechanism, gas flow profile, and material volume per total

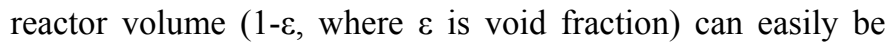
monitored using this configuration. A stationary system is implemented for decontamination of heavier and/or metallic materials (i.e. diagnostics, system components, etc.). Variables/Parameters such as pressure, temperature, and ultraviolet (U.V.) catalyst exposure can easily be monitored using this configuration [3].

\section{A. Rotary System Configuration}

The key components of the rotary system (Fig. 2) are an ozone generation/injection unit; a stainless steel reaction chamber, equipped with baffles for agitation of materials; an 
open-ended aluminum feed pipe, to allow for permeation of ozone throughout the chamber; a rotary mixer, capable of variable revolutions per minute; and a negative pressure exhaust duct, for release to stack or clean-up process. A stainless steel mesh basket-liner allows for easy loading and unloading of chamber (the baffles mentioned above are riveted to this basket), and a rotating (silicon rubber o-ring) seal provides a means for free rotation of chamber. The unit operates on $120 \mathrm{~V} \mathrm{AC}$, using a standard three-prong electrical interface. A system schematic is given below [3].

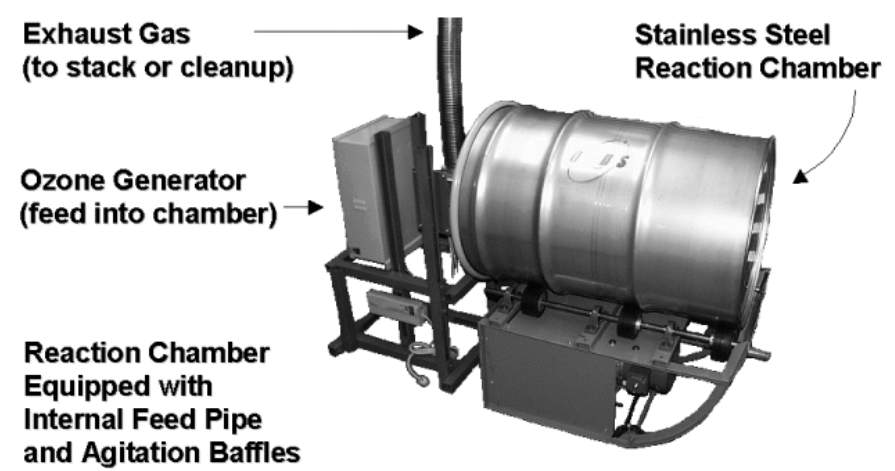

Fig. 2 Rotary Configuration for Oxidative Tritium Decontamination System. Implemented for decontamination of light materials (PPE, MLLW).

\section{B. Stationary System Configuration}

The key components of the stationary system (Fig. 3) are an ozone generation/injection unit; a stainless steel vacuum chamber, equipped with standard Conflat ${ }^{\circledR}$ flange; inlet and outlet manual control valves; and a single tube inlet purge line feed to bottom of chamber. When applying U.V. light catalyst, a sapphire window (on Conflat ${ }^{\circledR}$ flange), minimizes U.V. light absorption, allowing $>70 \%$ transmittance through the window [1]. The chamber has the capability of achieving high vacuum or being pressurized to >760Torr, and has integrated temperature control. Effluent gas is exhausted to stack or clean-up process, via ozone resistant tubing. A system schematic is given below [3].

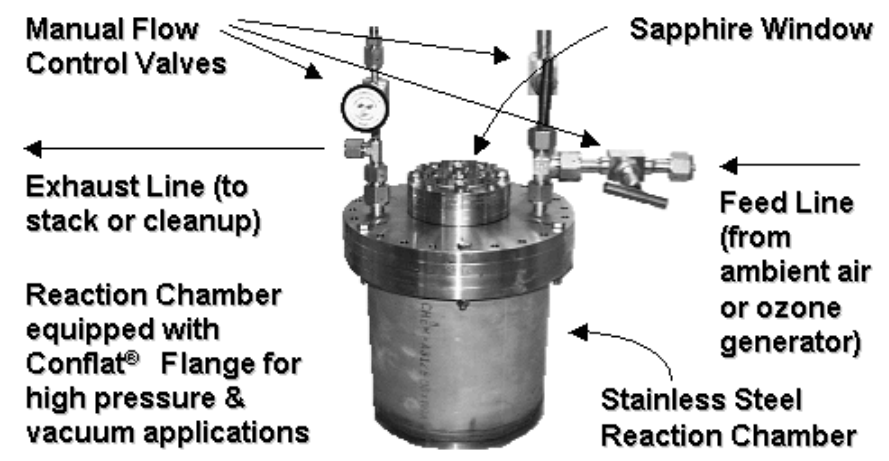

Fig. 3 Stationary Configuration for Oxidative Tritium Decontamination System. Implemented for decontamination of heavier and/or metallic materials (i.e. diagnostics, system components, etc.)

\section{Piston-Cylinder Configuration}

A system is currently being developed for the decontamination of materials containing tritium within the material bulk (sub-surface tritium deposition). The proposed design will operate via a piston-cylinder mechanism, and will be capable of rapid pressure increases of up to several atmospheres. By introducing a piston apparatus to the system, the reaction chamber volume can be significantly compressed, consequently increasing the ozone concentration within the reaction chamber (Fig. 4). This configuration will also allow for deeper ozone penetration into the material of concern [3].
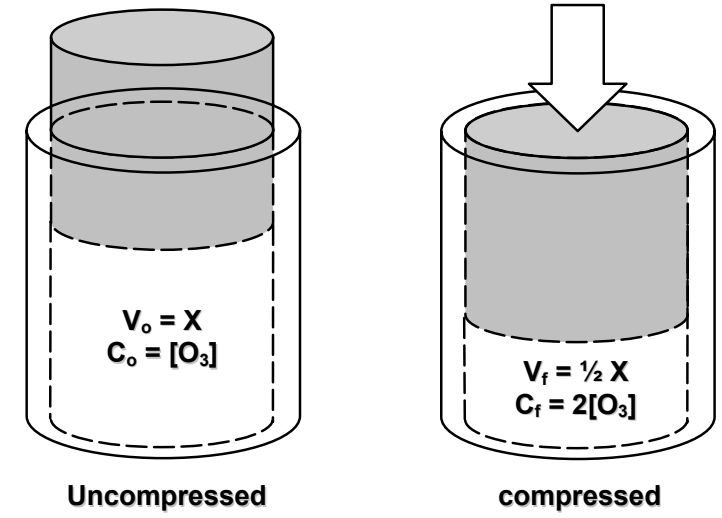

Fig. 4 Conceptual diagram of Piston-Cylinder Configuration. Note that at $1 / 2$ of initial volume, the ozone concentration is doubled (constant number of molecules contained in a compressible volume).

\section{REACTION CHEMISTRY}

The chemical reaction between ozone and diatomic hydrogen (all isotopic variations) follows an oxidationreduction (electron transfer) mechanism, by which ozone serves as the oxidizing agent. Due to the high instability of the ozone molecules, the mechanism can occur in the absence of a driving force (i.e. catalytic parameters). The mechanism involves a series of half-reactions, followed by the combination of hydrogen (oxidation number is +1) and oxygen (oxidation number is -2 ) ions to form hydrogen oxide (water), or tritium oxide if tritium isotope is involved. Chemical by-product of this reaction mechanism is a diatomic oxygen molecule. The reaction mechanism is given by (1), where $\mathrm{H}$ represents any isotope of hydrogen present in the system [3].

$$
\begin{array}{ll}
\text { Reaction: } & \mathrm{H}_{2}+\mathrm{O}_{3} \rightarrow \mathrm{H}_{2} \mathrm{O}+\mathrm{O}_{2} \\
\text { Mechanism: } & \mathrm{H}_{2} \rightarrow 2 \mathrm{H}^{+}+2 \mathrm{e}^{-} \\
& \mathrm{O}_{3}+2 \mathrm{e}^{-} \rightarrow \mathrm{O}^{2-}+\mathrm{O}_{2} \\
& 2 \mathrm{H}^{+}+\mathrm{O}^{2-} \rightarrow \mathrm{H}_{2} \mathrm{O}
\end{array}
$$

A series of side (secondary) reactions also can occur, the type and/or extent of which are governed by experimental conditions (i.e. temperature, pressure, etc.) and by specific chemical species present in the system. These reactions, though secondary in nature with respect to the mechanism expressed in (1), can often promote additional release of 
hydrogen isotopes. Examples include oxidation of carbon to carbon dioxide (and carbon monoxide), reaction of nitrogen (if present in feed) with hydrogen isotopes to yield tritiated ammonia, and degradation of plastics via oxidative dissociation of polymer chains [3].

Required duration of ozone exposure (adequate system runtime) is heavily dependant upon the concentration of pure ozone in the feed gas and the residence time in the reaction chamber. These parameters can be controlled in various ways, including adjustment of feed gas $\mathrm{O}_{2}$ concentration into the ozone generation unit (via pure oxygen or oxygen/inert gas mixture), adjustment of feed flow rate into reaction chamber, and adjustment of reactor volume. By passing feed gas through a drying agent/desiccant prior to entry into the reaction chamber, evaporation of tritium oxide will more readily occur (relative humidity within chamber is lowered), also shortening system run-time. This drying process also reduces possibility of the formation of hydroxyl radicals, which can hinder the primary reaction mechanism [3].

\section{DeCOMPOSITION Of EXCESS OZONE FOLLOWING (TRITIUM) OXIDATION PROCESS IN OTDS}

The OTDS ozone generation/injection unit produces gaseous state ozone at a concentration and rate relative to the overall unit flow rate. The performance output graph for the OTDS ozone generation/injection unit (Fig. 5) indicates that at the maximum ppm unit flow rate $(\approx 1 \mathrm{~L} / \mathrm{min})$, the volumetric part per million ozone content will be approximately 11674 ppm (Table II) [5]. At most, $10 \%$ of this ozone content will be consumed/disassociated during the OTDS process. The remaining process effluent is exhausted to HVAC ductwork. In most cases, this HVAC ductwork is constructed of ferrous metal, which exhibits corrosion when exposed to strong oxidizing agents (i.e. ozone) in high concentrations. In addition, ozone will degrade polymer-composite (i.e. silicon rubber) seals present in HVAC systems. Therefore, it is necessary to significantly reduce the release of ozone from the OTDS process. Several options for OTDS post-process ozone decomposition have been considered. In the following subsections, each option will be covered in detail.

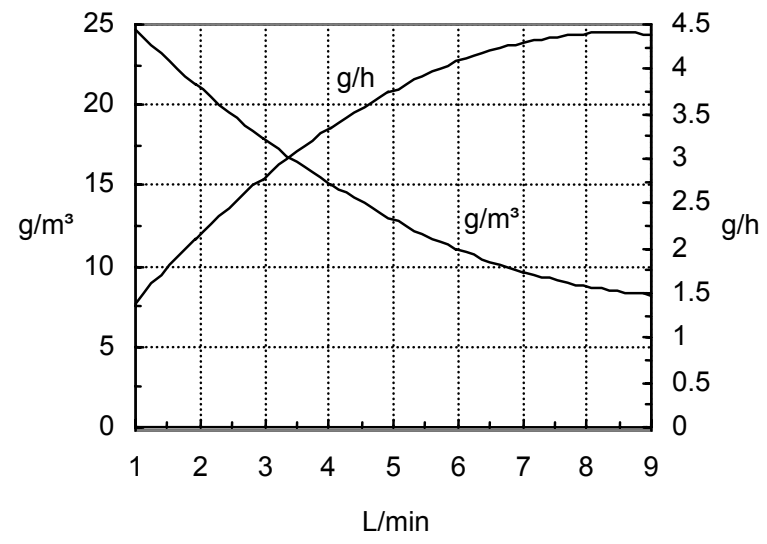

Fig. 5 Performance output for OTDS ozone generation/injection unit, as a function of overall unit flow rate
TABLE II

EVALUATION OF PART PER MILLION OZONE PRODUCTION BY OTDS OZONE GENERATION/INJECTION UNIT AS A FUNCTION OF OVERALL UNIT FLOW RATE

\begin{tabular}{lcccr}
\hline $\mathbf{L} / \mathbf{m i n}$ & $\mathbf{g} / \mathbf{m} \mathbf{3}$ & $\mathbf{g} / \mathbf{L}$ & $\mathbf{~ m o l} / \mathbf{L}$ & $\mathbf{p p m}$ \\
\hline 1.0 & 25 & 0.0250 & $5.2 \mathrm{E}-04$ & 11674 \\
2.0 & 21 & 0.0210 & $4.4 \mathrm{E}-04$ & 9806 \\
3.0 & 18 & 0.0175 & $3.6 \mathrm{E}-04$ & 8172 \\
4.0 & 15 & 0.0150 & $3.1 \mathrm{E}-04$ & 7004 \\
5.0 & 13 & 0.0130 & $2.7 \mathrm{E}-04$ & 6070 \\
6.0 & 11 & 0.0113 & $2.3 \mathrm{E}-04$ & 5253 \\
7.0 & 10 & 0.0100 & $2.1 \mathrm{E}-04$ & 4670 \\
8.0 & 9 & 0.0088 & $1.8 \mathrm{E}-04$ & 4086 \\
9.0 & 8 & 0.0080 & $1.7 \mathrm{E}-04$ & 3736 \\
\hline
\end{tabular}

Part per million data calculated using graph provided in Fig. 5.

\section{A. Thermal Decomposition}

Ozone (triatomic oxygen) can be converted to diatomic oxygen via application of energy in the form of heat. For complete conversion to occur, ozone must be held at a temperature exceeding $300^{\circ} \mathrm{C}$ for an approximate 3 second duration (2) [6]. Process energy requirements for thermal decomposition are therefore significantly large. Although much of the energy can be recovered via heat exchange device (approximately $65 \%$ ), the relatively high operating cost associated with process heat load input facilitates further research into alternative ozone decomposition methods [7].

$$
2 \mathrm{O}_{3}(g) \frac{\Delta \mathrm{T} \geq 300^{\circ} \mathrm{C}}{\Delta \mathrm{t} \geq 3 \mathrm{~s}}>3 \mathrm{O}_{2}(g)
$$

\section{B. Activated Carbon Decomposition}

Removal of moderate ozone levels in OTDS effluent can be achieved via implementation of activated carbon (particulates or filter medium). Ozone molecules that come in contact with the carbon surface react to form carbon dioxide (carbon monoxide secondary) via direct chemical oxidation (3). To remove adequate levels of ozone from the effluent stream, an approximate 3 second residence time must be achieved [6].

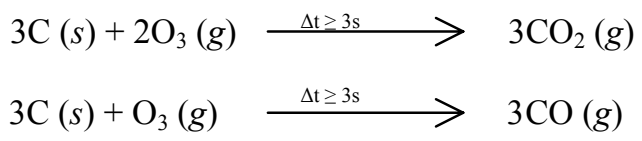

As with any process involving a chemical reaction, ozone decomposition is governed by the limiting reagent (in this case, activated carbon). As the reaction proceeds, carbon is consumed, and eventually reaches the breakthrough point (ratio of the effluent ozone concentration to the feed ozone concentration is no longer favorable, Fig. 6). Activated carbon must therefore be replaced periodically [7]. 


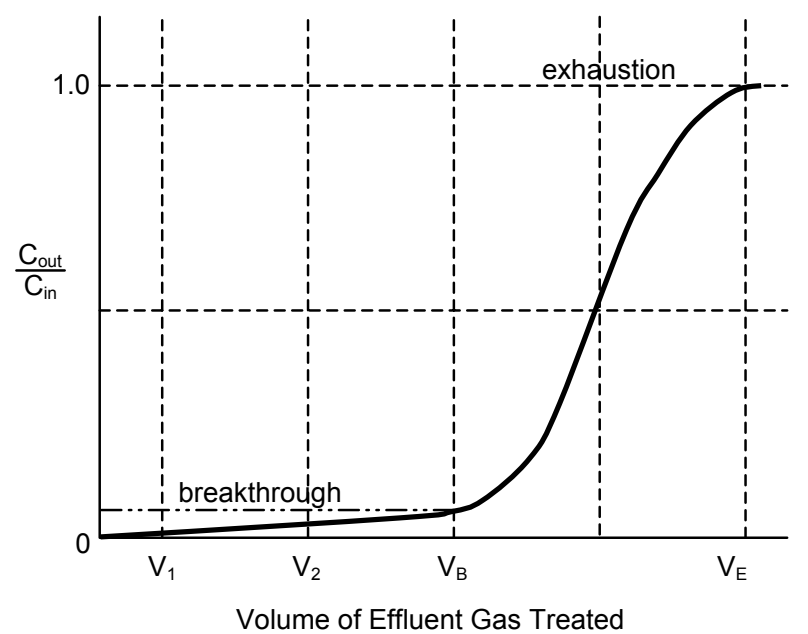

Fig. 6 Sample breakthrough curve for activated carbon decomposition of ozone; concentration ratio at breakthrough $\approx 0.1-0.5$

\section{Hopcalite Catalyst Decomposition}

The chosen method for OTDS post-process ozone decontamination (as per negative aspects of thermal and activated carbon decomposition) is use of hopcalite (manganese dioxide based) catalyst [8]. The hopcalite decomposition process can be implemented under ambient temperature conditions $\left(22-23^{\circ} \mathrm{C}\right)$, and, unlike activated carbon, is not consumed as ozone is converted to diatomic oxygen. Hopcalite decomposition requires an approximate 0.36-0.72 second residence time, and can effectively achieve $\geq 99 \%$ conversion of up to $120000 \mathrm{ppm}$ ozone [6]. Exact percent conversion of ozone to diatomic oxygen is demonstrated by (4) [9].

$$
\begin{array}{rl} 
& \% \mathrm{O}_{3} \text { Destruction }=100 /[1+\exp (\mathrm{F})] \\
\mathrm{F}=-8.7+0.22 \mathrm{x}_{1}-2.16 \mathrm{x}_{2}-0.74 \mathrm{x}_{3}+0.018 \mathrm{x}_{4}+0.018 \mathrm{x}_{5} \\
\mathrm{x}_{1}=1000 /(\mathrm{T}+25) & \mathrm{T}=\text { temperature, }{ }^{\circ} \mathrm{C} \\
\mathrm{x}_{2}=\ln (\tau-0.03)+1.4 & \tau=\text { residence time, } \mathrm{s} \\
\mathrm{x}_{3}=\mathrm{v} & \mathrm{v}=\text { linear velocity, ft/s } \\
\mathrm{x}_{4}=\mathrm{RH}-67 & \mathrm{RH}=\text { relative humidity } \\
\mathrm{x}_{5}=\left(\mathrm{x}_{2}\right)\left(\mathrm{x}_{4}\right) & \% \text { at } 23^{\circ} \mathrm{C}
\end{array}
$$

\section{Method For EfFicient Removal Of Tritium Oxide FROM OTDS REACTION CHAMBER}

As per the primary reaction mechanism associated with the OTDS process, elemental tritium is reacted with ozone to form tritium oxide. However, tritium oxide formed via this reaction mechanism is not removed through chemical process (majority of tritium oxide remains as condensate on material surfaces). Consequently, a physical process (i.e. evaporation) must be implemented to facilitate tritium oxide removal.

Tritium oxide possesses thermodynamic properties almost identical to that of hydrogen oxide $\left(\mathrm{H}_{2} \mathrm{O}\right.$, non-isotopic). Evaporation of tritium oxide is thus achieved via application of thermodynamic parameters quite similar to those required for hydrogen oxide evaporation. Parameters include the following: temperature $(\mathrm{T})$, pressure $(\mathrm{P})$, and percent relative humidity $(\% \mathrm{RH})$ within the OTDS reaction chamber. These parameters (variable) determine the overall evaporation rate (also a function of tritium oxide condensate surface area, air/gas velocity over tritium oxide condensate surface, and tritium oxide latent heat of vaporization). Theoretical determination of tritium oxide evaporation rate at specific time is given in (5) [10].

$$
\begin{array}{cl}
\mathrm{r}=\varnothing(\mathrm{A})\left(\mathrm{C}_{1}+\mathrm{vC}_{2}\right)\left(\mathrm{p}^{*}-\mathrm{P}_{\mathrm{DP}}\right) /\left(\Delta \hat{\mathrm{H}}_{\mathrm{V}}\right) \\
\text { where: } & \mathrm{r}=\text { evaporation rate (mass/time) } \\
& \phi=\text { dimensional consistency factor } \\
& \mathrm{A}=\text { condensate surface area } \\
& \mathrm{C}_{1}=\text { constant }(\text { energy/time/area }) \\
& \mathrm{C}_{2}=\text { constant }(\text { energy/time/area }) \\
& \mathrm{v}=\text { air/gas velocity surface } \\
& \mathrm{p}^{*}=\text { saturation vapor pressure } \\
& \mathrm{P}_{\mathrm{DP}}=\text { saturation pressure at dewpoint } \\
& \Delta \hat{\mathrm{H}}_{\mathrm{V}}=\text { latent heat of vaporization }
\end{array}
$$

\section{SUMMARY}

The development of an oxidative tritium decontamination system provides a method for the reduction of tritium surface contamination of various components and items. Expendable items can be detritiated to levels at or slightly above background, and re-usable items can be de-tritiated for near free release levels, and for use in controlled areas. Initial experimentation employing ozone as a tritium decontamination gas has indicated tritium surface activity reductions (on MLLW) by as much as $80 \%$ after only moderate exposure time (45min - Fig. 7) [3]. Introduction of low wavelength ultraviolet radiation $(<250 \mathrm{~nm})$ accelerates the reaction process, in some cases by more than $100 \%$ (Fig. 8) [11]. The capital cost and operation cost of the system is relatively low, thus making the system an ideal approach to tritium decontamination processes.

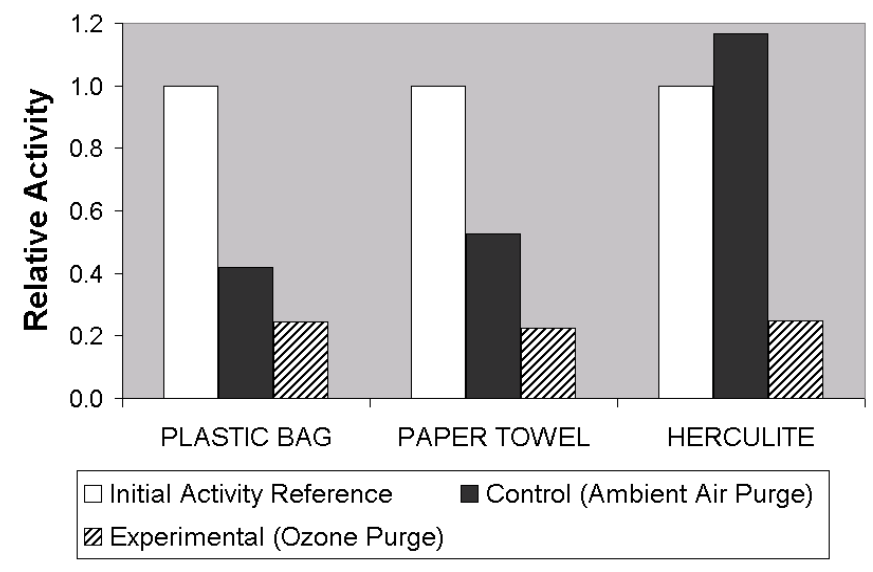

Fig. 7 MLLW decontamination via OTDS Rotary System Configuration. Chart displays activity reductions relative to initial surface activity. 


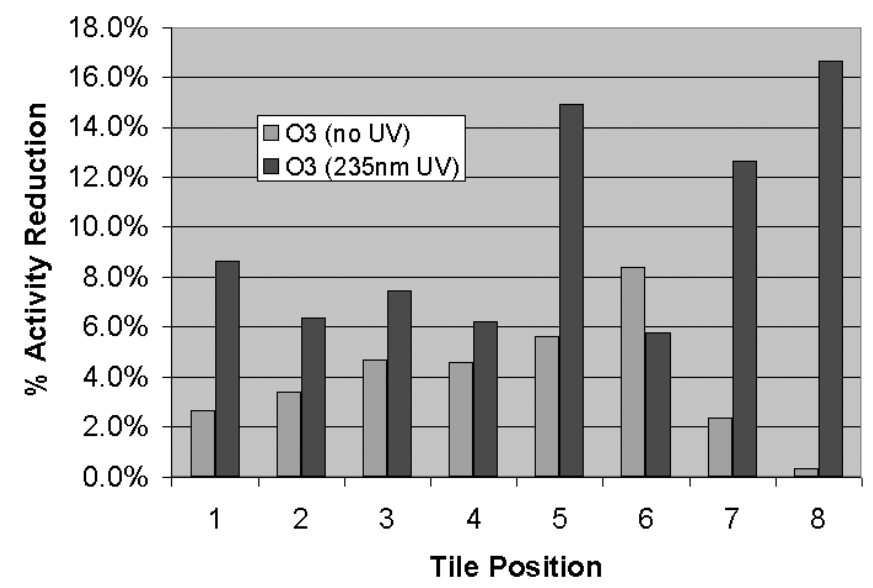

Fig. 8 Percent activity reduction at different locations on RF tile. Data series 1 (light gray) represents an ozone exposure under normal experimental conditions (CONTROL group, no ultraviolet radiation present in system). Data series 2 (dark gray) represents an ozone exposure subject to $12 \mathrm{~W}, 235 \mathrm{~nm}$ ultraviolet radiation (EXPERIMENTAL group). The figure demonstrates that (position 6 is exception) this wavelength of UV stimulus positively affects surface tritium activity reduction.

\section{ACKNOWLEDGEMENT}

The authors of this paper would like to acknowledge Denis Shaltis and William Walker of the PPPL Tritium Systems staff for their contributions toward the fabrication of system components. Allen Planeta of PPPL Health Physics Staff is also recognized for his continuing support in system experimentation and testing.

\section{REFERENCES}

[1] C. A. Gentile, et. al. "Tritium Decontamination of TFTR D-T Graphite Tiles Employing Ultra Violet Light and a Nd:YAG Laser" $18^{\text {th }}$ IEEE/NPSS Symposium on Fusion Engineering. October 25-29, 1999, Albuquerque, New Mexico.

[2] C. A. Gentile, G. L. Guttadora, J. J. Parker "Oxidative Tritium Decontamination System," Invention No. 01-1812-1, United States Patent and Trademark Office, submitted May 2001.

[3] C. A. Gentile, J. J. Parker, G. L. Guttadora "Oxidative Tritium Decontamination of Tritiated Materials Employing Ozone Gas", $6^{\text {th }}$ International Conference on Tritium Science and Technology, November 2001, Tsukuba, Japan.

[4] T. Itoh, et. al. "Developmental Study of Dry Decontamination for Tritiated Wastes," $6^{\text {th }}$ International Conference on Tritium Science and Technology, November 2001, Tsukuba, Japan.

[5] Cascadian CNOA4 Product Specification. $\mathrm{O}_{3}$ Water Systems, Inc. November 28, $2001<\mathrm{http}$ ://www.o3water.com/Products/Specifications/ CNOA4.htm>.

[6] J. Sigmund "Catalytic Destruction of Ozone: A Cost Effective Approach to Controlling Off-Gas Ozone Emissions," in Water Conditioning \& Purification, March 2001, pp. 50-53.

[7] D. R. Simpson "Method for the Continuous Destruction of Ozone," Patent No. 5951957, United States Patent and Trademark Office, September 14, 1999.

[8] N. Singh, K. S. Pisarczyk "Stable High Temperature Manganese Based Oxidation Catalyst," Patent No. 5260248, United States Patent and Trademark Office, November 9, 1993.

[9] CARULITE $^{\circledR}$ Air Purification Catalyst. Carus Chemical Company. October 25, $2001<\mathrm{http}: / /$ www.caruschem.com/CRLTAIR.HTM>.

[10] W. H. Carrier "The Temperature of Evaporation," ASHVE Transactions, vol. 24 (1918).

[11] J. D. Geiser, et.al. "The Vibrational Distribution of $\mathrm{O}_{2}\left(\mathrm{X}^{3} \Sigma_{\mathrm{g}}^{-}\right)$Produced in the Photodissociation of Ozone Between 226 and 240 and at $266 \mathrm{~nm}$." Journal of Chemical Physics. Vol. 112, No. 3, 15 January 2000. 


\section{External Distribution}

Plasma Research Laboratory, Australian National University, Australia

Professor I.R. J ones, Flinders University, Australia

Professor J oão Canalle, Instituto de Fisica DEQ/IF - UERJ , Brazil

Mr. Gerson O. Ludwig, Instituto Nacional de Pesquisas, Brazil

Dr. P.H. Sakanaka, Instituto Fisica, Brazil

The Librarian, Culham Laboratory, England

Library, R61, Rutherford Appleton Laboratory, England

Mrs. S.A. Hutchinson, JET Library, England

Professor M.N. Bussac, Ecole Polytechnique, France

Librarian, Max-Planck-Institut für Plasmaphysik, Germany

J olan Moldvai, Reports Library, MTA KFKI-ATKI, Hungary

Dr. P. Kaw, Institute for Plasma Research, India

Ms. P.J . Pathak, Librarian, Insitute for Plasma Research, India

Ms. Clelia De Palo, Associazione EURATOM-ENEA, I taly

Dr. G. Grosso, Instituto di Fisica del Plasma, Italy

Librarian, Naka Fusion Research Establishment, J AERI, J apan

Library, Plasma Physics Laboratory, Kyoto University, J apan

Research Information Center, National Institute for Fusion Science, J apan

Dr. O. Mitarai, Kyushu Tokai University, J apan

Library, Academia Sinica, Institute of Plasma Physics, People's Republic of China

Shih-Tung Tsai, Institute of Physics, Chinese Academy of Sciences, People's Republic of China

Dr. S. Mirnov, TRINITI, Troitsk, Russian Federation, Russia

Dr. V.S. Strelkov, Kurchatov Institute, Russian Federation, Russia

Professor Peter Lukac, Katedra Fyziky Plazmy MFF UK, Mlynska dolina F-2, Komenskeho Univerzita, SK-842 15 Bratislava, Slovakia

Dr. G.S. Lee, Korea Basic Science Institute, South Korea

Mr. Dennis Bruggink, Fusion Library, University of Wisconsin, USA

Institute for Plasma Research, University of Maryland, USA

Librarian, Fusion Energy Division, Oak Ridge National Laboratory, USA

Librarian, Institute of Fusion Studies, University of Texas, USA

Librarian, Magnetic Fusion Program, Lawrence Livermore National Laboratory, USA

Library, General Atomics, USA

Plasma Physics Group, Fusion Energy Research Program, University of California at San Diego, USA

Plasma Physics Library, Columbia University, USA

Alkesh Punjabi, Center for Fusion Research and Training, Hampton University, USA

Dr. W.M. Stacey, Fusion Research Center, Georgia Institute of Technology, USA

Dr. J ohn Willis, U.S. Department of Energy, Office of Fusion Energy Sciences, USA

Mr. Paul H. Wright, Indianapolis, Indiana, USA 
The Princeton Plasma Physics Laboratory is operated by Princeton University under contract with the U.S. Department of Energy.

\author{
Information Services \\ Princeton Plasma Physics Laboratory \\ P.O. Box 451 \\ Princeton, NJ 08543
}

Phone: 609-243-2750

Fax: 609-243-2751

e-mail: pppl_info@pppl.gov

Internet Address: http://www.pppl.gov 